\title{
Interference of spray volume, fruit growth and rainfall on spray deposits in citrus black spot control periods
}

\begin{abstract}
Interferência do volume de calda, crescimento dos frutos e precipitação pluviométrica sobre os depósitos da pulverização no período de controle da mancha preta dos citros
\end{abstract}

\author{
Demétrius de Araújo ${ }^{I^{*}}$ Carlos Gilberto Raetano ${ }^{\mathrm{I}}$ Hamilton Humberto Ramos ${ }^{\mathrm{II}}$ \\ Douglas Sampaio Ribeiro da Rocha ${ }^{\text {II }}$ Evandro Pereira Prado ${ }^{\text {III }}$ Viviane Corrêa Aguiar ${ }^{\text {II }}$
}

\section{ABSTRACT}

Citrus black spot (CBS) caused by Guignardia citricarpa is one of the most serious Brazilian citrus diseases. This study aims to assess the interference of three application volumes in spray deposition citrus fruit, as well as fruit growth and rainfall effects on spray deposit reduction during the CBS control period. The experiment was carried out in a commercial citrus orchard, with sixteen-year-old trees of the Valencia variety, in Mogi Guaçu, São Paulo State, Brazil. The

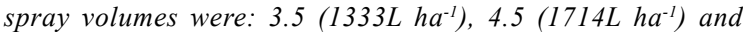
$8.5\left(3238 \mathrm{~L} \mathrm{ha}^{-1}\right)$ litres per tree, sprayed by an airblast sprayer using fungicides at recommended periods for disease control. The spray deposition quantification and residue was done by spectrophotometry using a copper oxychloride tracer. Samples were collected in three height zones of the tree (top, middle and bottom) and placed between trees on line plantation. Spray depositions were significantly smaller in the first application as a consequence of reduced fruit size. The spray losses on average for each day of rainfall ranged from 4.0 to $5.7 \%$. There was no significant difference between application volumes regarding spray deposition on citrus fruit,which makes possible the reduction of application volumes, however, it is necessary to improve spraying techniques for the top zone of the citrus tree.

Key words: technology application, airblast sprayer, disease, fungicide.

\section{RESUMO}

A pinta preta ou mancha preta em citros (MPC) está entre as mais importantes doenças da citricultura brasileira. O trabalho teve como objetivo avaliar a interferência de três volumes de pulverização na deposição da calda em frutos cítricos e o efeito do crescimento dos frutos e da precipitação pluviométrica na redução dos depósitos, durante o periodo de controle da doença. O experimento foi conduzido em pomar comercial com 16 anos, da variedade Valencia, na região de Mogi Guaçu, SP. Os tratamentos consistiram dos volumes de 3,5 (1333L ha $\left.\mathrm{L}^{-1}\right) ; 4,5$ (1714L ha $\mathrm{h}^{-1}$ ) e 8,5 (3238L $\left.h^{-1}\right)$ L planta ${ }^{-1}$, aplicados por um pulverizador de arrasto com jato transportado, utilizando fungicidas nos periodos recomendados para controle da doença. A quantificação dos depósitos/resíduos foi por espectrofotometria, usando oxicloreto de cobre como traçador. Os frutos foram coletados em três alturas da planta, na região entre plantas da linha de plantio. Os depósitos foram significativamente inferiores na primeira aplicação, como consequência do tamanho reduzido do fruto. As perdas dos depósitos médios de calda, por dia de chuva, variaram de 4,0 a 5,7\%. Não ocorreram diferenças significativas entre volumes de aplicação quanto à deposição sobre os frutos, possibilitando a redução de volumes, contudo, torna-se necessário melhorar as técnicas de aplicação na parte superior da planta.

Palavras-chave: tecnologia de aplicação, pulverizador de jato transportado, doença, fungicida.

\section{INTRODUCTION}

The Brazilian citrus industry has many phytosanitary problems. The citrus black spot (CBS) causes serious damage to the sector and is widespread in many citrus producing areas in the

\footnotetext{
IDepartamento de Proteção Vegetal, Defesa Fitossanitária, Faculdade de Ciências Agronômicas (FCA), Universidade Estadual Paulista (UNESP), 18610-307, Botucatu, SP, Brasil. E-mail: demaraujo@yahoo.com.br. "Corresponding author.

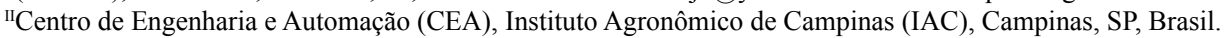

IIIDepartamento de Engenharia Agronômica, Faculdade de Ciências Agrárias e Tecnológicas (FCAT), Universidade Estadual Paulista (UNESP), Campus de Dracena, Dracena, SP, Brasil.
} 
world like South African, Taiwan, Australian and South America (YONOW et al., 2013). CBS is caused by Guignardia citricarpa (Kiely), a foliar and fruit disease of citrus (KOTZÉ, 1981).

$\mathrm{CBS}$ is a quarantine disease, a fact that greatly increases the damage when it occurs in plantations and loading dealing with citrus export to countries free of the fungus. The disease affects the fruit appearance by damaging the skin, making them unsuitable for the fresh fruit market (FEICHTENBERGER, 1996). With fungus favorable conditions it also causes the premature fall of fruit which may reduce production by up to $80 \%$ (KLOTZ, 1978). ARAÚJO et al. (2013) reported losses up to $50 \%$ caused by CBS treatments with fungicides application.

The citrus orchards have a long susceptibility period to this disease which ranges from 20 to 24 weeks after flower fall (KLOTZ, 1978). In general, the main control attempts have been by spraying fungicides in the period previously determined (a spray scheduling program). The amount of spraying to control this disease has increased in the orchards, which in turn has increased the production costs, and has often not provided effective control.

Sprayings with high volume rates are still quite common in Brazilian orchards, despite reports that spray volume has no direct relation with control efficacy (RAMOS et al., 2007a). Pesticide spray application to citrus trees in Brazil involves applications of very high volumes $(28 \mathrm{~L}$ tree $^{-1}$ ) (RAMOS et al., 2007b).

There is still little study about how, and how much, it is possible to efficiently reduce the application volume while maintaining CBS control. Some experiment results in Brazil, aiming to control CBS (RAMOS et al., 2008a, b), have induced questions about what the amounts of reduction really are in the application volumes that can be practiced in the field, without changing the recommended fungicide concentrations in the spraying in order to obtain a sufficient deposition for adequate CBS control.

This study aims to assess the effect of application volume reduction on citrus fruits in CBS recommended control periods and to assess the deposits reduction at the end of sprayings intervals, evaluating the effects of rainfall and fruit growth in relation to this spray deposits reduction.

\section{MATERIAL AND METHODS}

The field trial was conducted in a commercial citrus orchard, with sixteen-yearold trees of the Valencia variety in Mogi Guaçu district, São Paulo State, Brazil (22 ${ }^{\circ} 18^{\prime}$ S; $\left.47^{\circ} 00^{\prime} \mathrm{W}\right)$. The trees were planted at a spacing of $3.5 \mathrm{~m} \times 7.5 \mathrm{~m}$. Individual trees were $4.5 \mathrm{~m}$ in height and $5.0 \mathrm{~m}$ wide. The median volume canopy of tree was $99.5 \mathrm{~m}^{3}$.

Experimental design and sprayer

To setup the treatments were considered the application volumes conventionally practiced in a commercial orchard of $8.5 \mathrm{~L}$ tree $^{-1}$ and other alternative volumes of $4.5 \mathrm{~L}$ tree ${ }^{-1}$ and $3.5 \mathrm{~L}$ tree $^{-1}$, which were estimated by preliminary evaluation with an application volume of between 1.0 and 6.0L tree ${ }^{-1}$. According to RAMOS et al. (2008a, b) reducing spray volume from 6.0 to $4.0 \mathrm{~L}$ tree $^{-1}$ did not significantly show any difference on spray deposits or coverage on Valencia fruits.

Treatments were organized in a splitsplit plots design. Main plots consisted of three spray volumes, split-plots were collected from zones in the tree (fruits on the top, middle and bottom) and the split-split-plots consisted of four sampling periods (Nov. 08, Dec. 06, Jan. 08 and Feb. 14). Main plot size consisted of 490 trees configured as 70 trees per row by 7 rows replicated four times. The split-plots were 5 trees selected randomly in the three central rows of the plots. The other trees were considered as a border to avoid spray interference between adjacent plots. The split-split plots periods were chosen according to recommended fungicidal control of CBS (FUNDECITRUS, 2005).

For the first and second sprayings a copper fungicide at $175 \mathrm{~g}$ of commercial product (c.p.) $\left(840 \mathrm{~g} \mathrm{~kg}^{-1}\right.$ of a.i. copper oxychloride) $100 \mathrm{~L}^{-1}$ was applied. For the third and fourth sprayings the systemic fungicides Derosal $500 \mathrm{CS}^{\odot}$ at $100 \mathrm{~mL}$ c.p. $100 \mathrm{~L}^{-1}\left(50 \%\right.$ of carbendazin) and Comet $^{\odot}$ at $15 \mathrm{~mL}$ c.p. $100 \mathrm{~L}^{-1}(25 \%$ of pyraclostrobin) were applied, respectively. Systemic fungicides were mixed with copper oxychloride at $175 \mathrm{~g}$ c.p. $100 \mathrm{~L}^{-1}$. The $\mathrm{Cu}^{2+}$ cation in copper oxychloride was used as a tracer. All the fungicides applied were mixed with mineral oil $\left(0.25 \% \mathrm{v} \mathrm{v}^{-1}\right)$.

An airblast sprayer, Arbus 2000/Export model (Jacto Co.), dragged by a MF-275 tractor was used for all sprayings. The tractor speed was $3.7 \mathrm{~km}$ $\mathrm{h}^{-1}$ for all volumes. The sprayer was equipped with 
a special spray boom working in a two-sided mode and containing a higher number of spray nozzles than conventional spray booms. Environmental conditions during spraying were: air temperature range of $23-26^{\circ} \mathrm{C}$, wind speed of $1-7 \mathrm{~km} \mathrm{~h}^{-1}$ and air relative humidity of $60-86 \%$.

Hollow cone tips were selected to produce a droplet spectrum with volumetric median diameter (VMD) around the range 150$200 \mu \mathrm{m}$; reported by Ramos et al (2007a) like a range of good efficiency deposition in citrus. The application volumes were: $3.5 \mathrm{~L}$ tree ${ }^{-1}$ [Nozzle type (NT): D3/DC25 (disc/ disc core); Working pressure

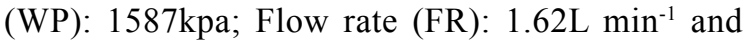
VMD: $134 \mu \mathrm{m}$ ], 4.5L tree ${ }^{-1}$ [NT: D3/DC45; WP: 1587kpa; FR: 2.08L $\mathrm{min}^{-1}$ and VMD: $\left.154 \mu \mathrm{m}\right]$ and 8.5 [NT: D6/DC45; WP: 1587kpa; FR: 3.94L min $^{-1}$ and VMD: $163 \mu \mathrm{m}]$.

\section{Fruits spray deposits}

After spraying, six fruits were collected on each 5 trees per split-plot (120 fruits on each treatment). Fruit collection zones were chosen at three heights bottom (ground to $1.1 \mathrm{~m}$ ), middle (1.1 to $2.2 \mathrm{~m}$ ), and top (2.2 to $4.0 \mathrm{~m})$ into the canopy (the inter-plant canopy region of the planting row) on one side between two consecutive plants. The establishment of the selection sites was due to the high difficulty of spray droplets to reach this part (WHITNEY et al., 1989; ARAÚJO et al., 2013). Two fruits were collected and individually packaged - in plastic bags - from each canopy collection site. Fruits were collected before each spraying and 43 days after the last spraying in order to quantify the reduction of copper fungicide deposition in the spray intervals.

In the laboratory, each sample of fruit was individually washed by adding $50 \mathrm{~mL}$ of the extractor solution $\mathrm{HCl} 0.2 \mathrm{Mol} \mathrm{L}^{-1}$ to recover the copper ion. Unsprayed fruits were included in the sampling to test for any background copper. The resultant solution was measured using an atomic absorption spectrophotometry (Perkin-Elmer 2380 model).

Fruit growth and rainfall measurements

The fruit's surface area was estimated by surface area to weight relationship. A hundred fruits in each sample period were collected randomly. Fruits were weighed and measured for diameter on two axes (smaller and bigger) by a digital pachymeter to calculate fruit surface area. Considering the fruits as a perfect sphere, it was possible to estimate the surface area and regression analysis was done to construct the equation.

By the results of the spray volume retained and the area of each fruit it was possible to calculate the spray volume deposit on fruits $\left(\mu \mathrm{L} \mathrm{cm}^{-2}\right)$.

\section{Statistical analyses}

Statistical tests were performed using statistical program ASSISTAT (SILVA \& AZEVEDO, 2002). Deposit and residue data was analyzed using a completely randomized split-split plots design with three volumes, three sampling positions and four evaluation periods with twenty replications. After a significant $(\mathrm{P}<0.05) \mathrm{F}$ test, Tukey's multiple range tests were used to determine differences between averages at 5\% level.

\section{RESULTS AND DISCUSSION}

According to analysis of fruit area in the protection period of the citrus orchard (141 days), it is evident that fruits had significant increases in all evaluations, but in different proportions (Figure 1). It is clear that the greatest growth rate corresponds to the interval between the first and second spraying, with the increase of average area from $4.7 \mathrm{~cm}^{2}$ to $20.7 \mathrm{~cm}^{2}$, which equates the increase of $440 \%$ compared to initial size.

This expressive growth is extremely detrimental to the effect of pesticides with contact action mode due to a reduced redistribution (copper-based fungicides). When the fruit has been $100 \%$ covered by the product with contact action, an area increase of 4.4 times will provide a reduction of spray coverage from approximately 23\%. Moreover, according to VICENT et al. (2009) and TIMMER et al. (1998), the displacement of copper deposits due to the expansion of fruits area reduces their tenacity and the fungicide coverage is more easily washed off by rainfall. VICENT et al. (2009) emphasize that, due to the large dilution of fungicide deposits caused by the fast fruit growth during the initial months after its formation, a spraying schedule of 28 days may not be adequate to protect the fruit during spring and early summer times.

After the second application the fruits still continued growing, but at lower rates compared to the first period at values of $226 \%$ (2.2 times), $170 \%$ and $140 \%$ respectively of the second period until the fifth evaluation period (Mar. 29). It is possible to check that the interval between the third to the fourth period (40 days) 


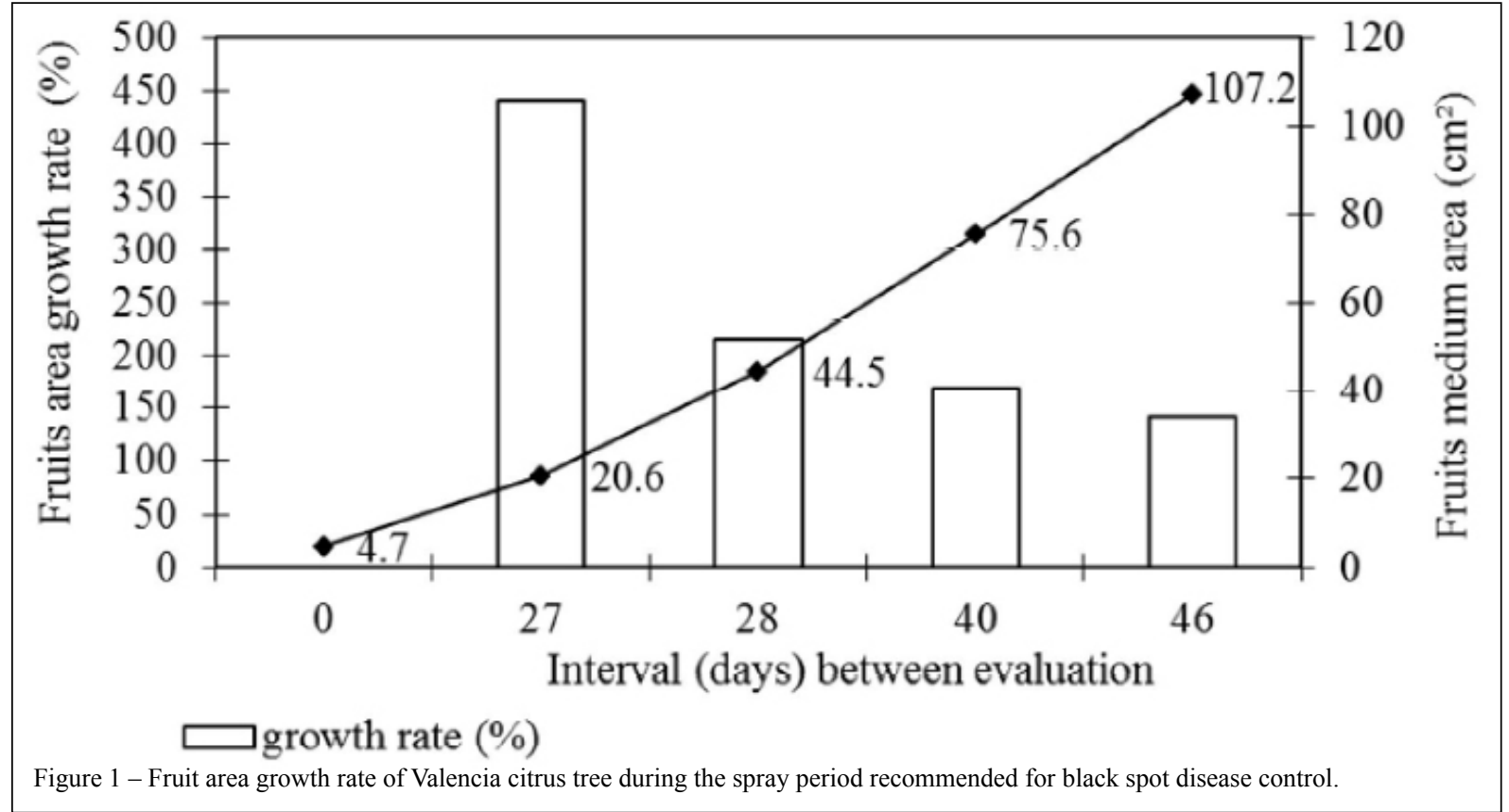

and the fourth to the fifth period (46 days) were considerably higher when compared with the initial periods ( 27 and 28 days). Thus, the daily fruit growth was also lower when compared with the initial evaluation period.

The analysis of variance of spray deposit values show that spray volumes (L tree $e^{-1}$ ) and interactions with other factors involved in this study were not significant by $\mathrm{F}$ test $(\mathrm{F}=1.78, \mathrm{P}>0.05)$. As reported in this research, CUNNINGHAM \& HARDEN (1998) there was also no observed significant difference between spray volumes on mature citrus trees with 4000 and $2000 \mathrm{~L} \mathrm{ha}^{-1}$ and with a tractor speed of $1.7 \mathrm{~km}$ $\mathrm{h}^{-1}$ on spray deposits on leaves. The same authors observed that spray volume applied above 2000L $\mathrm{ha}^{-1}$ increases losses by run-off and decreases leaf spray recovery.

ARAÚJO et al. (2013), studying the interference in reducing spray volume, showed there was no difference with a reduction from 3238 to $1714 \mathrm{~L} \mathrm{ha}^{-1}$ on CBS control, but the volume of $1333 \mathrm{~L} \mathrm{ha}^{-1}$ was not appropriate to control this disease. Reducing spray volumes as showed in other trials CUNNINGHAM \& HARDEN (1998); CUNNINGHAM \& HARDEN (1999) can bring lots of advantages like increasing retention of spray volume on the target area, and reduced target losses such as canopy run-off. However, caution may have to be considered of applying low volumes when using pesticides registered on a dose per volume basis. Applying pesticides with registered uses based on application rates expressed per volume of spray mixture may not be efficient once the lethal doses could not be reached.

Significant differences on spray deposits $(\mathrm{F}=16.9, \mathrm{P}<0.01)$ occurred only in the vertical tree zone and in the interaction of vertical tree zones versus sampling periods $(\mathrm{F}=2.3, \mathrm{P}<0.05)$. No significant difference was observed between spray deposit levels of different zones of the tree in the first spraying. Subsequently, they were lower in the tree top zone, with exception in the third spraying, where in top and middle zones the values of deposits were significantly lower than those obtained in the bottom zones of the tree.

The characteristic of mature citrus trees are a high leaf mass and the leaves form a larger physical barrier to spray droplets that prevents them from reaching the fruit. It must also be consider the difficulty of the spray nozzles to leave deposits in the top part of the tree due to the greater distances to this tree zone. ARAÚJO et al., (2013) reported that the top zone of the trees is the most critical position for spray deposits to reach on citrus. CUNNINGHAM \& HARDEN (1998) and ALBRIGO et al. (2005) also reported that fruit 
inside the canopy, as well as those from the top zone of the tree, received less spray deposits according to most of the sprayers used in citrus orchards. CUNNINGHAM \& HARDEN (1998) reported that citrus leaves deposits in the low zone were greater than in the top and in the middle zone, as was observed in this research, after a third application, on fruit deposits. According to these authors the spray deposits on leaves in different tree height zones corresponded to the air flow pattern produced by the sprayer. The highest velocity air is produced at the fan cowling and introduced to the lower section of the tree canopy from a distance of $0.5 \mathrm{~m}$ producing the highest spray deposits on leaves. Air introduced into the middle and the top section of the tree canopy was of lower velocity and from a distance of $1-2 \mathrm{~m}$ resulting in lower deposits on the leaves.

The lower values of deposits observed on the fruits placed in the top zone of the trees was probably due to the sprayer used in this research, and which was not favorable to the release of the fungicide spray on these targets. CUNNINGHAM \& HARDEN (1999) evaluating different sprayers and spray volumes to mature citrus trees observed that the highest spray deposit on fruits was achieved with the Barlow tower sprayer, and that this sprayer had the lowest variability between fruits deposits through the entire canopy sample zone. The explanation of the low variability of deposits with Barlow tower sprayers compared to standard low-profile air blast sprayers is probably that air-tower conveyors overcome the inability of low-profile air blast sprayers to direct sufficient airflow into the upper tree canopy.

In evaluating each vertical zone of the tree it was noted that for all zones the deposits of the first spray were lower than those found in other spray periods (Table 1). This can be explained by the period of trees with high leaf mass making a physical barrier to fruits, particularly those with a small size $\left(4.69 \mathrm{~cm}^{2}\right)$. Therefore, the initial formation of the citrus fruits is more critical to obtain an adequate spray deposit, according to the spraying program of CBS control. In the other sprays, the spray deposit levels were slightly higher in the second spraying followed by a stabilization trend of the values. This probably occurred by fruit growing and the "umbrella effect" caused by the leaves reducing intensity.

The average data for residues $(\mu \mathrm{L}$ spray solution $\mathrm{cm}^{-2}$ ) for the three application volumes during evaluation periods, and rainfall amounts in the interval between spraying, as well as the relation of these factors to spray deposits reduction, is shown in table 2 .

Rainfall ranged from 14.3 to $26.4 \mathrm{~mm}$ day $^{-1}$ and caused a reduction of the copper retained on fruits of between 31.5 and $86 \%$ in spray intervals, and from 4.0 to $5.7 \%$ per day of rainfall. Larger rainfall volumes do not always equate to higher losses. This fact could be explained by precipitation intensity factor (time between the beginning and end of precipitation in each day), however, the rainfall intensity factor has not been considered in this study.

The daily deposit losses on fruit could to be used as a reason to replace the current system of "schedule applications" on CBS control - which does not take into consideration the rainfall amount - in a system in which the daily deposition losses of different periods according to the rainfall could be estimated, it would allow to define the time when the next application is necessary. Thus, it would be necessary to firstly conduct the research aiming to

Table 1 - Mean values of fruit spray deposits after four spraying periods recommended to black spot disease control in three vertical sampling zones of the citrus tree.

\begin{tabular}{|c|c|c|c|c|}
\hline \multirow[t]{2}{*}{ Vertical Zone } & \multirow[b]{2}{*}{ First $\left(4.69 \mathrm{~cm}^{2}\right)$} & \multirow[b]{2}{*}{ Second $\left(20.65 \mathrm{~cm}^{2}\right)$} & \multirow{2}{*}{ Third $\left(44.55 \mathrm{~cm}^{2}\right)$} & \multirow[b]{2}{*}{ Fourth $\left(75.56 \mathrm{~cm}^{2}\right)$} \\
\hline & & & & \\
\hline Top & 4.99 a C & $14.79 \mathrm{~b} \mathrm{~A}$ & $10.23 \mathrm{~b} \mathrm{~B}$ & $12.46 \mathrm{bAB}$ \\
\hline Middle & 5.18 a C & 18.98 a A & $11.68 \mathrm{~b} \mathrm{~B}$ & $14.82 \mathrm{abB}$ \\
\hline Bottom & 4.77 a C & 19.86 a A & 15.48 a B & $15.84 \mathrm{a} \mathrm{B}$ \\
\hline Mean & 12.42 & & & \\
\hline
\end{tabular}

Means followed by different lowercase letters in columns and uppercase in rows are significantly different ( $\mathrm{P}<0.05$, Tukey's test). C.V. vertical zone: $23 \%$; C.V. spray: $26.4 \%$; LSD column: 3.1 ; LSD row: 3.52 . 
Table 2 - Effect of rainfall on the spray deposits losses (residue) on the fruit, along the interval between sprays.

\begin{tabular}{|c|c|c|c|c|}
\hline \multirow{2}{*}{ Factors } & \multirow[b]{2}{*}{$1^{\mathrm{a}} /(4.69)$} & \multirow{2}{*}{$2^{\mathrm{a}} /(20.65)$} & \multirow[b]{2}{*}{$3 \frac{\mathrm{a}}{} /(44.55)$} & \multirow[b]{2}{*}{$4^{\mathrm{a}} /(75.56$} \\
\hline & & & & \\
\hline Mean deposits $\left(\mu \mathrm{L}\right.$ solution $\left.\mathrm{cm}^{-2}\right)$ & 4.98 & 17.88 & 12.46 & 14.37 \\
\hline Residue evaluation (days after spraying) & 27 & 32 & 36 & 43 \\
\hline Mean residue $\left(\mu \mathrm{L}\right.$ solution $\left.\mathrm{cm}^{-2}\right)$ & 3.36 & 2.49 & 3.39 & 7.89 \\
\hline Rainfall in period (mm) & 114 & 253 & 366 & 139 \\
\hline Rainfall days & 8 & 15 & 14 & 9 \\
\hline Mean rainfall (mm rainfall day ${ }^{-1}$ ) & 14.3 & 16.8 & 26.4 & 15.4 \\
\hline Losses by rainfall day $(\%)$ & 3.9 & 5.7 & 5.2 & 4.8 \\
\hline Total reduction in the period $(\%)$ & 31.5 & 86.0 & 72.9 & 43.7 \\
\hline
\end{tabular}

find the minimum fungicide amount per fruit area $\left(\mathrm{cm}^{2}\right)$ to control the pathogen.

Considering the data of deposition reduction in vertical zones, except for the second period, the fruits placed in the top of the tree tend to have a greater reduction of spray deposits between spray intervals (Table 3 ). Thus the greater exposure of this part to climatic factors, especially rainfall, combined with the associated trend of smaller deposits in this tree zone because of the equipment used can be detrimental to the adequate treatment of the fruit.

\section{CONCLUSION}

The increase in the fruit area provides the improvement of spray deposits, even between trees, which is considered the hardest area to be reached by the spray. The average losses of spray deposits due to daily rainfall ranged from 4.0 to $5.7 \%$ with an average

Table 3 - Effect of rainfall on the spray deposits losses (residue) on the fruits in the vertical sector of the tree, along the spray intervals.

\begin{tabular}{|c|c|c|c|c|c|}
\hline \multirow{2}{*}{ Variables } & \multirow{2}{*}{ Vertical Sector } & \multicolumn{4}{|c|}{- -Spray/(mean area of fruits $\left.\mathrm{cm}^{2}\right)----$} \\
\hline & & $1^{\mathrm{a}} /(4.69)$ & $2^{\mathrm{a}} /(20.65)$ & $3^{\mathrm{a}} /(44.55)$ & $4^{\mathrm{a}} /(75.56)$ \\
\hline \multirow{3}{*}{ Mean of deposits $\left(\mu 1\right.$ solution $\left.\mathrm{cm}^{-2}\right)$} & Top & 4.99 & 15.44 & 10.23 & 12.51 \\
\hline & Middle & 5.18 & 18.92 & 11.68 & 14.89 \\
\hline & Bottom & 4.77 & 19.86 & 15.81 & 16.13 \\
\hline Residue evaluation (days after spraying) & & 27 & 32 & 36 & 43 \\
\hline \multirow{3}{*}{ Mean of residue $\left(\mu \mathrm{L}\right.$ solution $\left.\mathrm{cm}^{-2}\right)$} & Top & 2.90 & 2.29 & 1.91 & 5.61 \\
\hline & Middle & 3.55 & 2.89 & 3.95 & 7.76 \\
\hline & Bottom & 3.64 & 2.35 & 4.15 & 8.18 \\
\hline Rainfall in the period (mm) & & 114 & 253 & 366 & 139 \\
\hline Days with rainfall & & 8 & 15 & 14 & 9 \\
\hline Mean of rainfall (mm/rainfall day) & & 14.3 & 16.8 & 26.4 & 15.4 \\
\hline \multirow{3}{*}{ Losses by raifall day (\%) } & Top & 5.2 & 5.7 & 5.8 & 6.1 \\
\hline & Middle & 3.9 & 5.6 & 4.7 & 5.3 \\
\hline & Bottom & 3.9 & 5.9 & 5.3 & 5.5 \\
\hline \multirow{3}{*}{ Total reduction in the period $(\%)$} & Top & 41.9 & 85.2 & 81.3 & 55.2 \\
\hline & Middle & 31.5 & 84.7 & 66.1 & 47.9 \\
\hline & Bottom & 31.0 & 88.2 & 73.8 & 49.3 \\
\hline
\end{tabular}


rainfall between $14.3-26.4 \mathrm{~mm}$ day $^{-1}$. No difference to application volume was observed in spray deposition on Valencia fruit, providing the volumes reduction. However it is necessary to obtain better spray techniques to the top zone of the tree, where it is common to find smaller fungicides deposits and greater spray deposition losses due to rainfall.

\section{ACKNOWLEDEGMENTS}

The authors gratefully acknowledge Fundação de Amparo à Pesquisa do Estado de São Paulo (FAPESP) for providing financial support for this research and FUNDECITRUS for providing financial support and research facilities.

\section{REFERENCES}

ALBRIGO, L.G. et al. Development and testing of a recommendation system to schedule copper sprays for citrus disease control. Journal of ASTM International, West Conshohocken, v.2, n.9, p.1-12, 2005. Available from: <http://compass.astm.org/ download/JAI12904.32523.pdf>. Accessed: Jun. 05, 2015. doi: 10.1520/JAI12904.

ARAÚJO, D. et al. Interference of spray volume reduction in citrus black spot (Guignardia citricarpa Kiely) control in Valencia citrus fruits. Summa Phytopathologica, Botucatu, v.39, n.3, p.172-179, 2013. Available from: <http://repositorio.unesp.br/ bitstream/handle/11449/110165/S010054052013000300005 pdf? sequence $=1>$. Accessed: May 24, 2015. doi: 10.1590/S010054052013000300005 .

CUNNINGHAM, G.P.; HARDER, J. Reducing spray volumes applied to mature citrus trees. Crop Protection, Surrey, v.17, n.4, p.289-292, 1998. Available from: <http://ac.els-cdn.com/ S0261219498000076/1-s2.0-S0261219498000076-main.pdf? tid $=9 \mathrm{c} 49370 \mathrm{a}-\mathrm{a} 042-11 \mathrm{e} 5-\mathrm{a} 251-00000 \mathrm{aacb} 35 \mathrm{f} \& \mathrm{acdnat}=1449864$ 545 905d55d2c50ade4e4c6b8a5021154f5e>. Accessed: May 22, 2015. doi: 10.1016/S0261-2194(98)00007-6.

CUNNINGHAM, G.P.; HARDER, J. Sprayers to reduce spray volumes in mature citrus trees. Crop Protection, Surrey, v.18 p.275-281, 1999. Available from: <http://ac.els-cdn.com/ S0261219499000277/1-s2.0-S0261219499000277-main.pdf? tid=f016daea-a042-11e5-86b8-00000aacb35e\&acdnat $=1449864$ 686 9718940bcb8166e321799eff94465b93>. Accessed: Jun. 12, 2015. doi: 10.1016/S0261-2194(99)00027-7.

FEICHTENBERGER, E. Mancha-preta dos citros no Estado de São Paulo. Laranja,Cordeirópolis, v.17, p.93-108, 1996.

FUNDECITRUS. Calendário de pulverizações. In: FUNDECITRUS. Manual de pinta preta. Araraquara: Fundo de Defesa da Citricultura, 2005.11p.

KLOTZ, L.J. Fungal, bacterial, and nonparasitic diseases and injuries originating in the seedbed, nursery, and orchard. In REUTHER, W.et al. (Eds.). The citrus industry. Riverside: University of California, 1978. p.1-66.
KOTZÉ, J.M. Epidemiology and control of citrus black spot in South Africa. Plant Disease, St. Paul, v.65, p.945-950, 1981 Available from: $<$ http://www.apsnet.org/publications/plantdisease/ backissues/Documents/1981 Articles/PlantDisease65n12 945. pdf $>$. Accessed: Jan. 20, 2015. doi: 10.1094/PD-65-945.

RAMOS, H.H. et al. Estado da arte na tecnologia de aplicação em frutíferas - volume de aplicação e diâmetro de gotas. Summa Phytopathologica, Botucatu, v.33, supl., p.110-112, 2007a.

RAMOS, H.H. et al. Effect of carrier volume applied with an airblast sprayer on spray characteristics in citrus. Engenharia Agrícola, Jaboticabal, v.27, p.56-65, 2007b. Available from: $<$ http://www.scielo.br/pdf/\%0D/eagri/v27nspe/09.pdf > . Accessed: Jun. 12, 2015. doi: 10.1590/S0100-69162007000200009.

RAMOS, H.H. et al. Interação entre seis volumes de aplicação e três diâmetros medianos volumétricos de gotas sobre a deposição da calda de pulverização em diferentes tamanhos de frutos de laranjeira Valência. In: SIMPÓSIO INTERNACIONAL DE TECNOLOGIA DE APLICAÇÃO (SINTAG), 4., 2008, Ribeirão Preto, SP. Anais... Campinas: Instituto Agronômico, 2008a.1Cd-Rom.

RAMOS, H.H. et al. Interação entre dois ramais de pulverização, três arranjos de pontas de pulverização e duas pressões de trabalho para o controle da mancha preta sobre frutos de laranjeira Valência - cobertura da pulverização. In: SIMPÓSIO INTERNACIONAL DE TECNOLOGIA DE APLICAÇÃO (SINTAG), 4., 2008, Ribeirão Preto, SP. Anais... Campinas: Instituto Agronômico, 2008b.1Cd-Rom.

SILVA, F.A.S.; AZEVEDO, C.A.V. Versão do programa computacional Assistat para o sistema operacional Windows. Revista Brasileira de Produtos Agroindustriais, Campina Grande, v.4, n.1, p.71-78, 2002.

TIMMER, L.W. et al. Split applications of copper fungicides improve control of melanose on grapefruit in Florida. Plant Disease, St. Paul, v.82, sept, p.983-986, 1998. Available from: <http:// apsjournals.apsnet.org/doi/pdf/10.1094/PDIS.1998.82.9.983> Accessed: Jun. 12, 2015. doi: 10.1094/PDIS.1998.82.9.983.

VICENT, A. et al. Protectant activity of reduced concentration copper sprays against Alternaria brown spot on Fortune mandarin fruit in Spain. Crop Protection, Surrey, v.28, p.1-6, 2009. Available from: $<$ http://www.sciencedirect.com/science/article/pii/ S0261219408001208>. Accessed: Jun. 13, 2015. doi: 10.1016/j. cropro.2008.07.004.

YONOW, T. et al. CLIMEX modelling of the potential global distribution of the citrus black spot disease caused by Guignardia citricarpa and the risk posed to Europe. Crop Protection, v.44, 18 28, 2013. Available from: $<\mathrm{http}: / / \mathrm{www}$. sciencedirect.com/science/ article/pii/S0261219412002797>. Accessed: Jun. 13, 2015. doi: 10.1016/j.cropro.2012.10.006.

WHITNEY, J.D. et al. A field investigation to examine the effects of sprayer type, ground speed and volume rate on spray deposition in Florida citrus. Journal of Agricultural Engineering Research, Silsoe-Bedfordshire, v.42, p.275-283, 1989. Available from: <http:// www.sciencedirect.com/science/article/pii/0021863489900309>. Accessed: Feb. 24, 2015. doi: 10.1016/0021-8634(89)90030-9. 